\title{
Green Algae Halimeda macroloba in Spermonde Archipelago: Phytochemical and In Vitro Antibacterial Studies
}

\author{
Lulu Adilla Latifah ${ }^{1}$, Nunuk Hariani Soekamto², Akbar Tahir ${ }^{3, *}$
}

Lulu Adilla Latifah', Nunuk

Hariani Soekamto ${ }^{2}$, Akbar Tahir ${ }^{3, *}$

${ }^{1}$ Fisheries Science Department, Faculty of Marine Science and Fisheries, Hasanuddin University, Makassar, 90245, INDONESIA. ${ }^{2}$ Department of Chemistry, Mathematics and Natural Sciences Faculty, Hasanuddin University, Makassar, 90245, INDONESIA. ${ }^{3}$ Marine Science Department, Faculty of Marine Science and Fisheries, Hasanuddin University, Makassar, 90245, INDONESIA.

\section{Correspondence}

AkbarTahir

Marine Science Department, Faculty of Marine Science and Fisheries, Hasanuddin University, Makassar, 90245, INDONESIA. E-mail: akbar_tahir@mar-sci.unhas.ac.id

History

- Submission Date: 12-04-2020;

- Review completed: 18-05-2020

- Accepted Date: 08-06-2020.

DOI : 10.5530/pj.2020.12.141

Article Available online http://www.phcogj.com/v12/i5

Copyright

(c) 2020 Phcogj.Com. This is an openaccess article distributed under the terms of the Creative Commons Attribution 4.0 International license.

\section{ABSTRACT}

Background: Green algae Halimeda macroloba compounds active against human, fish, and shrimp pathogenic bacteria. It is one of the marine natural organisms (MNO) which is a diverse source of secondary metabolites. Objective: We have set our goal towards determining the antimicrobial potential of crude extracts of green algae H. macroloba. Materials and Methods: Three crude mixtures of Marine Natural Product (MNP) were obtained from macroalgae Halimeda macroloba (Lae-Lae island, Spermonde Archipelago) by extraction (n-hexane, ethyl acetate, and methanol were used as solvents). Results: Theses mixtures (phytochemical tests showed they contained steroids, terpenoids, and alkaloids) were screened for their activity against shrimp pathogenic bacteria (Vibrio harveyi (M-120), Aeromonas hydrophilla, and Vibrio parahaemolyticus (T-170)). The obtained results confirmed weak antibacterial activity of studied extracts of $H$. macroloba. The ethyl acetate extract was the most potent antimicrobial agent at a concentration of $4 \mu \mathrm{g} / 25 \mu \mathrm{l}$. The inhibition zones for the growth of $A$. hydrophilla (the most susceptible microorganism) and $V$. harveyi were at $8.27 \mathrm{~mm}$ and 8.23 $\mathrm{mm}$, respectively (inhibition zone was $15.2 \mathrm{~mm}$ for ciprofloxacin which was used as a positive control). Conclusion: They might be even used in the future as alternatives to conventional drugs in aquaculture.

Key words: Halimeda macroloba, Antibacterial Activity, Shrimp Pathogenic Bacteria, Phytochemical screening

\section{INTRODUCTION}

Green algae, known as green seaweed, emerged between 900 and 500 billion years ago. These algae belong to the eukaryotic photosynthetic group. One of them is Halimeda from the Udoteaceae family. This plant lives in habitats associated with coral reefs and contains high amounts of calcium carbonate. Therefore, Halimeda is classified as calcified or calcareous algae. ${ }^{1,2}$ According to several studies, Chlorophyta or green algae compounds active against human, fish, and shrimp pathogenic bacteria. It is one of the marine natural organisms (MNO) which is a diverse source of secondary metabolites. Natural products produced by various species of the genus Halimeda, including Halimeda macroloba, H. opuntia, H. macrophysa, $H$. gracilis, $H$. tuna, and $H$. renschi have been tested as potential antibacterial agent. ${ }^{3-7}$ For example, 4 new diterpenoids, halimedatrial-tipe compounds (structures 1,3,4,5) (Figure 1) which are potential as antibacterial agents ${ }^{8}$, have been isolated from several Halimeda species. Halimedatrial has antibacterial activity against a number of marine microorganisms, including Vibrio splendida, $V$. leiognathi, V. harveyi, Bacillus subtilis, and Staphylococcus aureus. ${ }^{9,10}$

Halimeda macroloba in Lae-Lae Island, Spermonde Archipelago, grows in complex environmental conditions (relatively high and changing salinity of seawater, high heavy metal content, and susceptibility to the surrounding organisms).
Environmental factors such as temperature, humidity, light intensity, water supply, minerals, and $\mathrm{CO}_{2}$, affect the growth and production of secondary metabolites in a plant. ${ }^{11}$ In order to survive, as a response to mentioned complex environmental factors, seaweed developed the ability to produce distinctive secondary metabolites.

A preliminary screening of the antimicrobial activity of crude algae extracts can help in the search of new antimicrobial seaweed metabolites. Such results can direct further phytochemical investigation and result in the isolation and structural elucidation of new natural products. For that reason, we have set our goal towards determining the antimicrobial potential of crude extracts of green algae Halimeda macroloba that grows in challenging environmental conditions of Spermonde Archipelago.

\section{MATERIALS AND METHODS}

\section{Collection of sample}

Green algae samples (Halimeda macroloba) were collected by hand (Snorkeling) from Lae-Lae Island, Makassar City, South Sulawesi Province, Indonesia. Samples were washed with seawater, freshwater, and distilled water to clean seaweed from salt, epiphytes, and other impurities. Then the wet samples $(1 \mathrm{~kg})$ were dried using a freeze drier. The sample was identified by the Productivity and Water Quality Laboratory, Faculty of Marine Science and Fisheries, Hasanuddin University, South Sulawesi Province, Indonesia. 


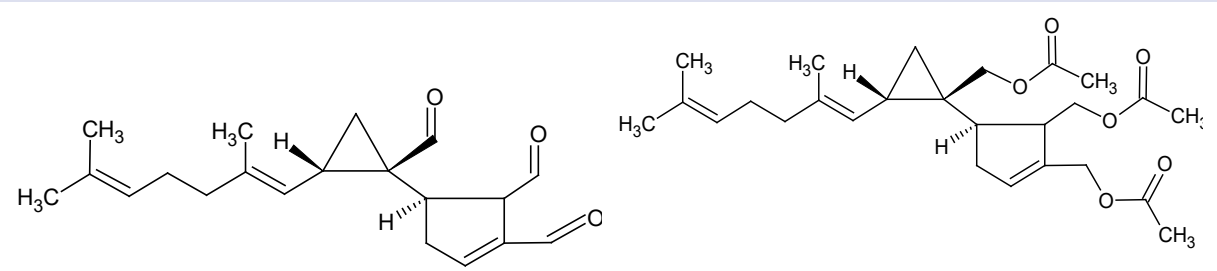

(1)

(2)<smiles>CC(=O)CC(CC(C)=O)CC(C=COC(C)=O)OC(C)=O</smiles><smiles>CC(=O)OC(/C=C(\C)CCC=C(C)C)Cc1cccc(C=O)c1</smiles>

(5)

Figure 1: Chemical structures of compound isolated from Halimeda sp.: Halimedatrial (1), halomedatriol triacetate (2), halimedalactone (3), halimedatetraacetate (4), and bis-nor dianpenoid (5).

\section{Instrumentation}

Buchner suction flasks and funnels, vacuum pumps, Buchi Rotavapor R-200, n-hexane, ethyl acetate, methanol (technical grade), and dimethyl sulfoxide (99\% purity Merck, Germany) for preparation of extracts.

\section{Extractions}

Samples were extracted in various solvents (a selection was based on the difference in their polarity). The extraction of secondary metabolites was carried out using n-hexane, ethyl acetate, and methanol; a ratio of powder extract to solvent was set 1:8 (w:v). ${ }^{12}$

\section{Antibacterial analysis}

Bacterial species (Vibrio harveyi (M-120), Aeromonas hydrophilla, and Vibrio parahaemolyticus (T-170) (shrimp pathogenic bacteria)) were donated by The Center for Brackish Water Aquaculture, Takalar, and Maros, South Sulawesi Province, Indonesia. The turbidity of the suspension was standardized against 0.5 McFarland using a spectrophotometer at a wavelength of $600 \mathrm{~nm} .{ }^{13}$ The bacterial inoculum was $10^{8} \mathrm{cfu} / \mathrm{ml}$. Antibacterial activity tests included positive, negative control and antibacterial activity tests for seaweed extract. The positive control test was carried out using ciprofloxacin antibiotics, and the negative control test used solvents (DMSO). The antimicrobial activity was determined by using slightly modified agar diffusion method. ${ }^{14-15}$ Sterile paper discs with a diameter of $6 \mathrm{~mm}$ were soaked in extracts with various concentrations. The concentrations were $4 \mu \mathrm{g}, 3 \mu \mathrm{g}$, and 2 $\mu \mathrm{g}(25 \mu \mathrm{l} / \mathrm{disc})$. The samples were incubated for 24 hours at $30^{\circ} \mathrm{C}$. The distinct zone around the paper disc is a sign of bacterial activity. Every experiment was conducted in triplicate. Inhibition zones $>15 \mathrm{~mm}$ were declared as strong, from 8 to $15 \mathrm{~mm}$ as moderate, and 1 to $8 \mathrm{~mm}$ as weak activities. ${ }^{16}$

\section{Phytochemical test}

A phytochemical identification test was used to determine the chemical content in a material qualitatively. Slightly modified previously described tests were used to determine the presence of alkaloid, flavonoid, steroid, and terpenoid compounds in the extracts. ${ }^{17}$

\section{RESULTS AND DISCUSSION}

Results of the phytochemical tests (Table 1) showed that the crude extracts have several classes of compounds. They were dominated by steroid/terpenoid compounds. A positive Wegner test suggested the presence of alkaloids. Although, the outcome of two other diagnostic tests for alkaloids (Meyer and Dragendorf) was negative. These results are consistent with the results of the previous studies, which stated that steroids and terpenoids are found in Halimeda $\mathrm{sp}^{5,8}$

Many representatives of these classes of compounds are strong antimicrobials. Thus, it was reasonable to expect that herein studied Halimeda extract will have at least some antimicrobial potential. The result of the antibacterial activity screening of four crude extracts against Gram-negative bacteria is summarized in Table 2. Of all studied samples, the crude ethyl acetate extract of Halimeda macroloba showed 
Table 1: Results of the phytochemical test.

\begin{tabular}{ccccc}
\hline \multirow{2}{*}{ No } & Phytochemicals & \multicolumn{3}{c}{ Extracts } \\
\cline { 3 - 5 } & N-hexane & Ethyl acetate & Methanol \\
\hline 1 & Wegner & + & + & + \\
2 & Meyer & - & - & - \\
3 & Dragendorf & - & - & - \\
4 & FeCl3 & - & - & - \\
5 & Lieberman-Buchard & ++ & ++ & ++ \\
\hline
\end{tabular}

${ }^{(-)}$Negative, ${ }^{(+)}$Weak positive, ${ }^{(+)}$Strong positive

Table 2: Average zone of inhibition for crude extracts Halimeda macroloba.

\begin{tabular}{|c|c|c|c|c|}
\hline \multirow{2}{*}{ Test samples } & \multirow{2}{*}{$\begin{array}{c}\text { Concentration } \\
(\mu \mathrm{g} / 25 \mu \mathrm{l})\end{array}$} & \multicolumn{3}{|c|}{ Inhibitory Zone (mm) } \\
\hline & & $A h^{a}$ & $V p^{b}$ & $V^{c}$ \\
\hline \multirow{3}{*}{ N-hexane } & 4 & 6.0 & 6.0 & 6.0 \\
\hline & 3 & 6.0 & 6.0 & 6.0 \\
\hline & 2 & 6.0 & 6.0 & 6.0 \\
\hline \multirow[t]{2}{*}{ Ciprofloxacin } & $40 \mathrm{ppm}$ & 14.2 & 13.0 & 11.8 \\
\hline & 4 & 8.27 & 6.0 & 8.23 \\
\hline \multirow[t]{2}{*}{ Ethyl acetate } & 3 & 7.39 & 6.0 & 7.83 \\
\hline & 2 & 7.04 & 6.0 & 7.17 \\
\hline \multirow[t]{2}{*}{ Ciprofloxacin } & 40 ppm & 15.2 & 10.6 & 12.3 \\
\hline & 4 & 6.0 & 6.0 & 6.0 \\
\hline \multirow[t]{2}{*}{ Methanol } & 3 & 6.0 & 6.0 & 6.0 \\
\hline & 2 & 6.0 & 6.0 & 6.0 \\
\hline Ciprofloxacin & $40 \mathrm{ppm}$ & 14.7 & 14.5 & 14.0 \\
\hline
\end{tabular}

${ }^{\mathrm{a}}$ Aeromonas hydrophila, ${ }^{\mathrm{b}}$ Vibrio parahaemolyticus, ' Vibrio harveyi

the highest antimicrobial activity. It inhibited the growth of two Gramnegative bacteria. Aeromonas hydrophilla with the inhibition zone of $8.27 \mathrm{~mm}$ at a concentration of $4 \mu \mathrm{g}$, was the most susceptible organism. Inhibition of the growth of Vibrio harveyi was slightly weaker at a concentration of $4 \mu \mathrm{g}$. It was $8.23 \mathrm{~mm}$. The value of the inhibition zones belonged to the category of weak. ${ }^{16}$ As previously shown, metabolites of green algae Halimeda macroloba exhibit a broad spectrum of antibacterial activity. ${ }^{3}$ Halimeda sp. showed to inhibit the growth of Gram-positive bacteria Bacillus cereus and Staphylococcus aureus.? While Halimeda opuntia metabolites are active against Escherichia coli and Staphylococcus aureus bacteria. The results are inhibition of $21 \mathrm{~mm}$ and $19 \mathrm{~mm}$ using $70 \%$ ethanol solvent. ${ }^{6}$

Other related studies to Halimeda, showed that methanolic extracts of $H$. macrophysa, $H$. gracilis, $H$. opuntia, and $H$. renschi inhibited growth of four types of bacteria. ${ }^{5}$ Extracts of another species $H$. tuna were tested against 10 types of human pathogenic bacterial strains. The results of this study showed that methanolic extract had higher antimicrobial potential, compared to ethanol and chloroform ones. ${ }^{4}$

The detected antibacterial activity of Halimeda extracts might be the outcome of the presence of terpenoid compounds. For example, compounds halimedatrial (1), halomedatriol triacetate (2), halimedalactone (3), halimedatetraacetate (4), and Bis-nor-Dianpenoid (5) have been isolated from several species of Halimeda sp. (Figure 1). These species have activity against bacteria, i.e. Vibrio sp., Bacillus subtilis, and Staphylococcus aureus. ${ }^{10}$ Halimedatrial (diterpenoid trialdehyde derivative), and halimedatetraacetate (tetraacetate diterpenoid derivative), secondary metabolites that are mostly found in Halimeda algae, are reported as antibacterial agents against some marine microorganisms.

Although crude extracts of Halimeda macroloba show only weak bacterial growth inhibition, it does confirm that some of its constituents are potential strong antimicrobials. Isolation and structure elucidation of pure constituents and their subsequent antimicrobial screening is needed to locate exact carriers of the detected activity. Thus, here presented data can be used as a starting point and illustrates potential of secondary metabolites from macroalgae in Lae-Lae Island as potential antibacterial agents against shrimp pathogenic bacteria. They might be even used in the future as alternatives to conventional antibiotics in aquaculture.

\section{CONCLUSION}

Halimeda macroloba crude extracts (3 different solvents) showed weak antibacterial activities against the tested organisms (3 Gram-negative bacteria). Ethyl acetate crude extract had the highest activity (disc diffusion method). The fast phytochemical test was used to determine the presence of certain classes of compound in the studied extracts and suggested that the extracts contained steroids, terpenoids, and alkaloids. However, further studies (isolation and structural elucidation) are needed to locate exact carriers of the observed antimicrobial activity.

\section{ACKNOWLEDGEMENTS}

This work was supported by the Ministry of Research, Technology, and Higher Education of the Republic of Indonesia through the PMDSU program. All authors declare no conflict of interest.

\section{REFERENCES}

1. Becker B, Marin B. Streptophyte algae and the origin of embryophytes. Ann Bot. 2009;103(7):999-1004

2. Hay ME, FenicalW. Marine plant-herbivore interactions: the ecology of chemical defense. Ann Rev Ecol and Syst. 1988;19:111-45

3. Govindasamy C, Narayani S, Arulpriya M, Ruban P, Anantharaj K, Srinivasan R. In vitro antimicrobial activities of seaweed extracts against human pathogens. $\mathrm{J}$ of Pharm Res. 2011;4(7):2076-7.

4. Indira K, Balakrishnan, Srinivasan M, Bragadeeswaran S, Balasubramanian T. Evaluation of in vitro antimicrobial property of seaweed (Halimeda tuna) from Tuticorin coast, Tamil Nadu, Southeast coast of India. African J of Biotechnol. 2013;12(3):284-9

5. Hendri M, Darmanto JS, Prayitno B, Radjasa OK. Antibacterial potential screening of Halimeda sp. on some types of pathogenic bacteria. Int $\mathrm{J}$ of Mar Sci. 2015;5:1-6. 
6. Mishra JK, Srinivas T, Sawhney S. Antibacterial activity of seaweed Halimeda opuntia from the coasts of south Andaman. Global J of Bio-Sci Biotechnol. 2016;5(3):345-8.

7. Razarinah W, Ross EER, Rahim NFA, Faridon BS, Radzun KA. Antimicrobial activity of marine green algae extract against microbial pathogens. Malaysian $J$ of Biochem and Mol Biol. 2018;2:42-6.

8. Paul VJ, Fenical W. Novel bioactive diterpenoid metabolites from tropical marine algae of the genus halimeda (chlorophyta). Tetrahedron. 1984;40:3053-62.

9. Paul VJ, Fenical W. Isolation of halimedatrial : chemical defense adaptation in the calcareous reef-building alga halimeda. Sci. 1983;221:747-9.

10. Fenical W, Paul VJ. Antimicrobial and cytotoxic terpenoids from tropical green algae of the family udoteaceae. Hydrol. 1984;116:135-40.

11. Ramakrishna A, Ravishankar GA. Influence of abiotic stress signals on secondary metabolites in plants. Plant Signal and Behav. 2011;6(11):172031.
12. El Shafay SM, Ali SS, El-Sheekh MM. Antimicrobial activity of some seaweeds species from Red Sea, against multidrug resistant bacteria. The Egypt $\mathrm{J}$ of $\mathrm{Aq}$ Res. 2016;42(1):65-74.

13. Chiao-wei C, Siew-ling H, Ching-lee W. Antibacterial activity of Sargassum polycystum C. Agardh and Padina australis Hauck (phaeophyceae). Afr J of Biotechnol. 2011;10(64):14125-31.

14. Bauer AW, Kirby WM, Sherris JC, Turck M. Antibiotic susceptibility testing by a standardized single disk method. Am J Clinic Pathol. 1966;45:493-6.

15. Zainuddin EN, Anshary H, Huyyirnah H, Hiola R, Baxa DV. Antibacterial activity of Caulerpa racemosa against pathogenic bacteria promoting "ice-ice" disease in the red alga Gracilaria verrucosa. J of Appl Phycol. 2019;31(5):3201-12.

16. Bansemir A, Blume M, Schröder S, Lindequist U. Screening of cultivated seaweeds for antibacterial activity against fish pathogenic bacteria. Aquaculture. 2006;252(1):79-84

17. Harborne JB. Phytochemical methods. A guide to modern techniques of plant analysis 2nd.Ed. New York: Chapman and Hall.Itd., p.37-141;1984.

\section{GRAPHICAL ABSTRACT}

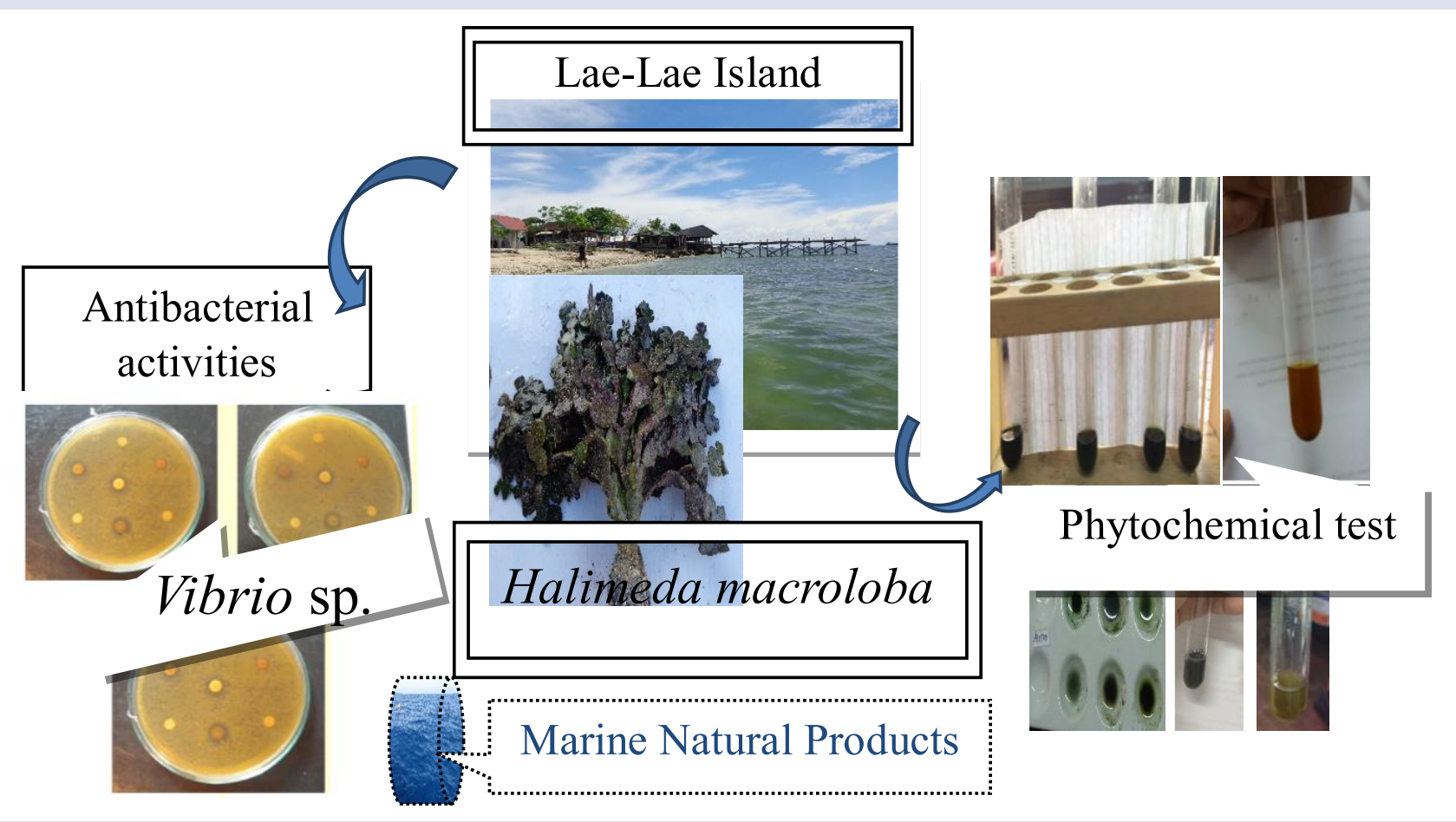

\section{ABOUT AUTHORS}

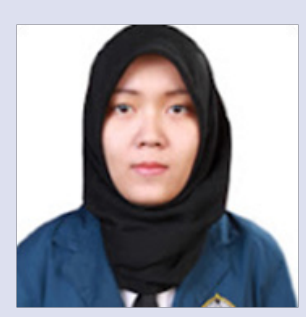

Lulu Adilla Latifah is a Doctoral Student at the Department of Fisheries Science, Faculty of Marine Sciences and Fisheries, Hasanuddin University, Indonesia. Lulu's current research focuses on studies of secondary metabolite compounds from marine natural products as antibacterial or anticancer drugs, especially marine sponge and macroalgae.

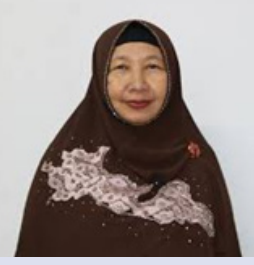

Nunuk Hariani Soekamto is a lecturer at the Department of Chemistry, Faculty of Mathematics and Natural Sciences, Hasanuddin University, Indonesia. She is a Professor in organic chemistry and interested in working in the field of natural product chemistry. 


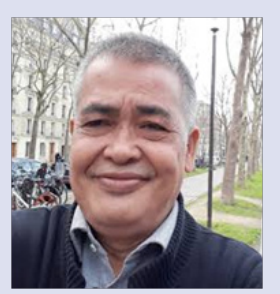

Akbar Tahir is a lecturer at the Department of Marine Sciences, Faculty of Marine Sciences and Fisheries, Hasanuddin University, Indonesia. He is Professor in Marine Pollution and Ecotoxicology. His current research interests are marine plastic and marine natural products.

Cite this article: Latifah LA, Soekamto NH, Tahir A. Green Algae Halimeda macroloba in Spermonde Archipelago: Phytochemical and In Vitro Antibacterial Studies. Pharmacogn J. 2020;12(5):1000-4. 